\title{
COMPUTATIONAL INVESTIGATION ON CSF FLOW ANALYSIS IN THE THIRD VENTRICLE AND AQUEDUCT OF SYLVIUS
}

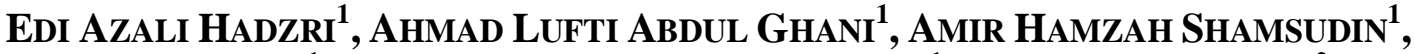

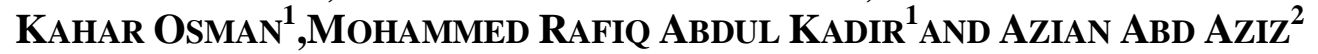 \\ ${ }^{1}$ Faculty of Mechanical Engineering, University Technology Malaysia, \\ 81310 Skudai, Johor, Malaysia \\ ${ }^{2}$ Department of Radiology, Kulliyyah of Medicine, \\ International Islamic University Malaysia, 25200, Kuantan, Malaysia. \\ arezareli@gmail.com.my
}

\begin{abstract}
In this study, a three dimensional (3D) model of the third ventricle and aqueduct of Sylvius derived from MRI scans was constructed by using Computational Fluid Dynamics (CFD) modeling. Cerebrospinal fluid(CSF) can be modeled as a Newtonian Fluid and its flow through the region of interest (ROI) was visualized using Engineering Fluid Dynamics (EFD). The constructed ROI was regarded as rigid walled and only steady state flow was able to be defined due to the limitations of current software. Different flow rate was simulated at the Foramen of Monro and a small stenosis was modeled at the middle of the aqueduct of Sylvius at a fixed location. This was made corresponding to normal patients with variation of CSF flow rate physiologically and abnormal patients with tumor causing obstruction to or within the aqueduct of Sylvius, respectively. Due to the small dimensions of the ROI geometry, gravity and complex external gravity that acted upon it was considered to be neglected. The results show as the flow rate increase, the pressure drop of CSF in the ROI proportionally increased. For normal CSF flow rate, the presence of stenosis in the aqueduct demonstrates a significant increased pressure drop.
\end{abstract}

ABSTRACT: Dalam kajian ini, model tiga dimensi (3D) untuk ventrikel ketiga dan akueduk Sylvius, yang terhasil daripada pengimejan resonans magnetik telah dikonstruksi menggunakan Permodelan Perkomputeran Dinamik Bendalir (Computational Fluid Dynamics (CFD)). Cecair serebrospinal (Cerebrospinal fluid (CSF)) dimodelkan sebagai bendalir Newtonan dan alirannya melalui kawasan kepentingan (region of interest (ROI)) digambarkan menggunakan Dinamik Bendalir Kejuruteraan (Engineering Fluid Dynamics $(E F D)$ ). Kawasan kepentingan yang dikonstruksi dianggap sebagai dinding tegar dan hanya aliran keadaan tunak yang dapat ditakrifkan berdasarkan pengehadan perisian komputer terkini. Kadar aliran yang berbeza disimulasikan di foramen monro dan laluan stenosis yang kecil dimodelkan di tengah-tengah akueduk Sylvius di satu lokasi yang telah ditetapkan. Kaedah ini dijalankan terhadap pesakit normal dengan variasi pada kadar aliran CSF, serta pesakit abnormal yang mempunyai tumor, penyebab sekatan terhadap atau melinkungi akueduk Sylvius. Disebabkan oleh ukuran geometri ROI kecil, tarikan graviti dan graviti luar kompleks yang bertindak ke atasnya diabaikan. Keputusan menunjukkan bahawa apabila kadar aliran meningkat, susutan tekanan CSF di dalam ROI meningkat dengan berkadar. Untuk kadar aliran CSF yang normal, kehadiran stenosis di dalam akueduk membuktikan pertambahan susutan tekanan yang ketara.

KEYWORDS: cerebrospinal fluid; CFD; magnetic resonance image; human ventricular system 


\section{INTRODUCTION}

The cerebrospinal fluid (CSF) is contained within and surrounds the brain and spinal cord [1]. It suspends the brain through its buoyancy force and protects it from impact on the cranial vault walls in cases of sudden head motion. The CSF further serves as an intermediary between blood and nervous tissue, providing the latter with nutrients and removing waste products. Within the skull, the cerebrospinal fluid is enclosed in the ventricles and the subarachnoid space [1]. The ventricles are four cavities interconnected by pathways. The two lateral ventricles are situated within the cerebral hemispheres. They communicate by way of the foramen of Monro with the third ventricle located in the median sagittal plane of the cerebrum. The fourth ventricle is connected to the third through the aqueduct of Sylvius .CSF is secreted from the bloodstream mainly in the choroid plexi of the brain ventricles at a rate of approximately $0.7 \mathrm{ml} / \mathrm{min}$ [2].A pulsatile motion, governed primarily by the cardiac cycle, is superimposed upon the steady flow caused by the CSF production; the interaction between the cardiovascular and the CSF systems is not fully understood. Traditionally, it was accepted that the CSF is drained mainly through the arachnoid villus system in the superior sagittal sinus.

When there is an imbalance between the formation and absorption of CSF, an excess of CSF will accumulate within the ventricles resulting in hydrocephalus. This will cause increased intracranial pressure, which leads to increase pressure onto the brain substance. This pressure increase depends on the degree of the hydrocephalus, which in turn is affected by the cause of the hydrocephalus. The causes of hydrocephalus can be due to excessive CSF production e.g. by a choroid plexus papilloma or from impairment or obstruction of CSF absorption. Hydrocephalus can cause death if not treated in a timely manner. The treatment of hydrocephalus include placement of a shunt catheter that can drain CSF from the ventricular spaces. Currently employed shunts contained valves that open when a given preset pressure threshold is reached. This is a very crude approach; a more sophisticated shunt that actively regulates the flow or pressure could potentially lead to much better results for the patients well-being. This justifies the need for a better understanding of the human ventricular system, an integral part of which is the CSF flow and pressure dynamics within the ventricles.

In children, a phenomenon where the ventricular systems is large or prominent but the children are asymptomatic can occur in which no surgical intervention is necessary and the ventricular size will attain the normal appearance as they grow older. This condition is termed benign enlargement of the subarachnoid spaces. However this condition can be confusing and of concerned particularly to a non-Pediatric Radiologists as to whether it is a hydrocephalus or otherwise.

There are basically three approaches to obtain the ventricular flow pattern. They are invivo measurements using, e.g., MRI velocimetry, CFD (computational fluid dynamics) simulations and experimental methods using a physical model of the ventricular system, while anatomical MRI scans can achieve excellent spatial and temporal resolution (e.g. the geometry reconstruction of the ventricular system in [3]), velocimetric MRI scans do not reach the same level of detail. Typical resolution (voxel size) of the latter is of the order of $0.5 \mathrm{~mm}$; which is insufficient to accurately capture the CSF flow pattern in the human ventricles, where important feature sizes are in the range of $1.5 \mathrm{~mm}$ (thickness of the 3rd ventricle, connection between ventricle chambers). While the resolution can be theoretically enhanced by increasing measurement time, this is not viable for in vivo measurements as the required resolution would lead to prohibitively long scan times. Extensive CFD simulations 
have been carried out in [3], where anatomical MRI scans were used to obtain the ventricle geometry. In this study, CFD was used to perform the same simulation that utilized local patients MRI scans.

\section{RESEARCH METHODOLOGY}

\subsection{Model Generation}

Structural MR imaging to define the ventricle and aqueduct boundaries was performed on a healthy female volunteer on a high field clinical imaging system (Philips Medical System $1.5 \mathrm{~T})$ by $256 \times 256$ resolution. The recorded pixel size was 0.7183 . The successful scanned images were transferred electronically to an MRI conversion software called AMIRA. This is integrated 3D image processing and editing software that allows MRI data to be converted into other suitable formats. For computational analysis, AMIRA uses threshold separation to capture various individual region in an MRI slice and was used to identify the contrast between CSF and brain material. The best setting for the contrast identification was between 57 until 303. After thresholding, the crude ROI (region of interest-consist of $3^{\text {rd }}$ ventricle, aqueduct of Sylvius and $4^{\text {th }}$ ventricle) was then undergo several steps to correct errors that resulted from the process. By Morphology operations, the model was dilated for 1 pixel and anatomical wall surrounding the ROI was successfully fabricated by using Boorlean operations. The generated model was then transferred to another software package called MAGICS under remesh tab. This software was used to make major alteration such as holes patching, geometry correction and volume reconstruction.2 flow inlet at Foramen of Monro was artificially created. Finished model was saved into STL format to be exported to another CFD software for flow analysis and stenosis modeling purpose.

\subsection{Numerical Methods}

The model was exported to the CFD package EFD (Engineering Fluid Dynamics), a meshing program that allowed the STL file to be converted from a wall fabricated hollow model into a volume filled with tetrahedral cells. A computational domain was automatically set at $0.013 \mathrm{~m} \times 0.036 \mathrm{~m} \times 0.034 \mathrm{~m}$ dimensions. Mininum gap sizes of $0.1 \mathrm{~mm}$ and a total number of 122909 mesh (47345 fluid cells and 75564 partial cells) was succesfully incoporated within the domain.For fluid volume of $1682.7 \mathrm{~mm}^{3}$,estimated meshing density was $73 \mathrm{~mm}^{-3}$. Due to the computer capabality limitation and time restriction, the effects of grid resolution on the results was not being performed.The volume mesh is comparable to the numerical solution of the fluid flow. Using EFD, the boundary conditions were applied to the model with foramina of Monro modeled as uniform flow rate inlets while the inferior end of aqueduct modeled as static pressure outlets. In the same software, CSF flow dynamics in the

ROI was calculated by solving the Navier-Strokes equations that govern 3D flow in incompressible fluids assumptions.

The model was set up as a rigid, non-slip with zero velocity walled, steady state model, despite the known flexibility of the ROI and the pulsatile nature of CSF. Gravity and external hydronamics pressure effect was not incorporated into this model and therefore buoyancy has been ignored in the Navier-Stokes equations. The fluid was modeled as CSF with a density of $1005 \mathrm{~kg} / \mathrm{m}^{3}$ and the flow modeled as laminar as it is secreted at very low velocities and therefore possess a low Reynolds Number. Using the same software, a small stenosis was modeled at fixed location and with different sizes along the aqueduct narrow channel to 
resemble actual aqueduct blockage that leads to hydrocephalus.

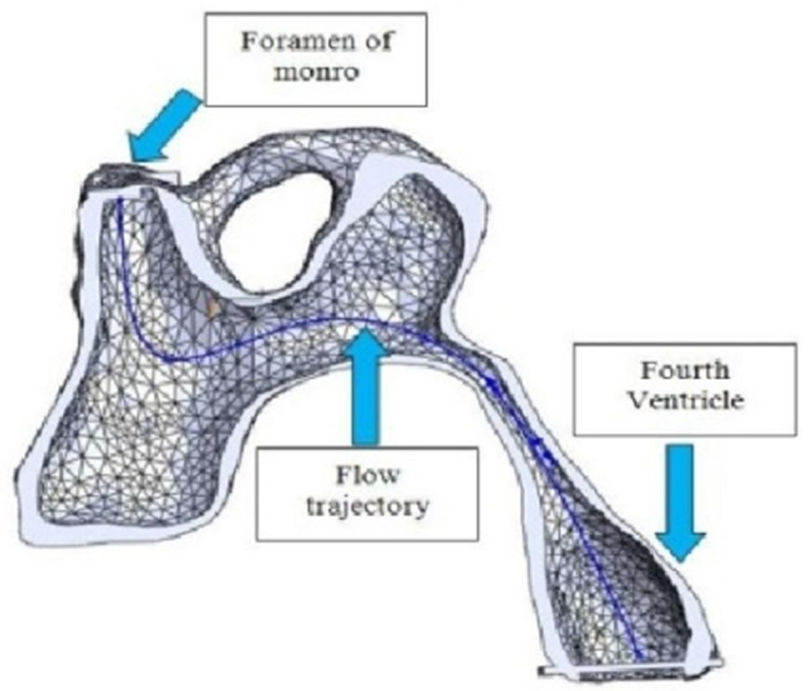

Fig. 1: A normal geometry that constructed from MRI scans, consist of third ventricle, aqueduct of Sylvius and fourth ventricle.

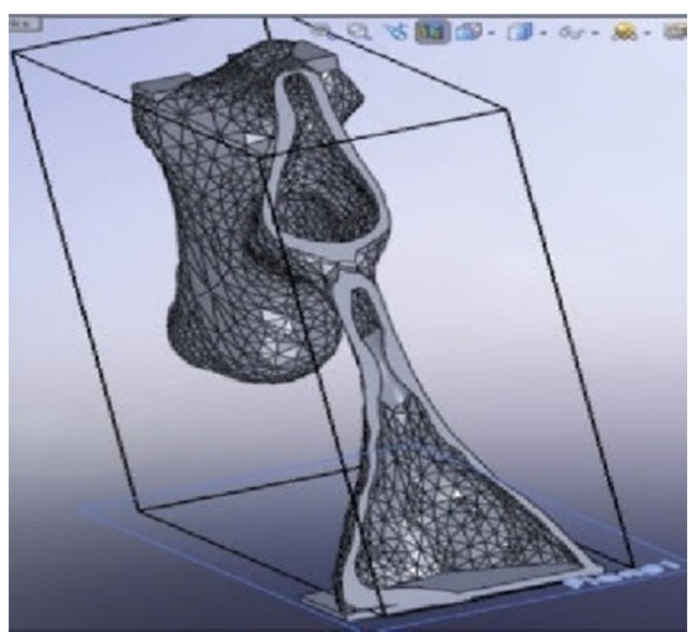

Fig. 2: A stenosed aqueduct was modeled on the geometry.

\subsection{Boundary Conditions}

By using EFD software, the STL format model was converted into SLDPRT format and the boundary condition for every inlet and outlet are defined. Flow rates defined in each cases are computed based on the findings by Linninger [4]. 
Table 1: $\quad$ Parameters for $3^{\text {rd }}$ ventricle and $4^{\text {th }}$ ventricle.

\begin{tabular}{cc}
\hline Parameter & Incompressible flow \\
\hline Flow rate $(\mathrm{ml} / \mathrm{s})$ & $0.0081,0.108,0.011667 .0 .0135$, \\
& $0.0162,0.0189$ \\
Static/Outlet Pressure & $500 \mathrm{~Pa}$ \\
Density & $1005 \mathrm{~kg} / \mathrm{m}^{3}$ \\
Stenosis location & Aqueduct of Sylvius \\
\hline
\end{tabular}

\section{RESULTS AND DISCUSSION}

We assumed that the both sides of the Foramen of Monro possess the same flow rate. A normal uniform flow rates inlets were designate at various flow rate to resembles normal and hydrocephalus conditions. $0.1166 \mathrm{ml} / \mathrm{s}(0.7 \mathrm{ml} / \mathrm{min})$ was regarded as normal flow rate based on the Friese [2] findings and the others parameter was referred to Linninger [4].

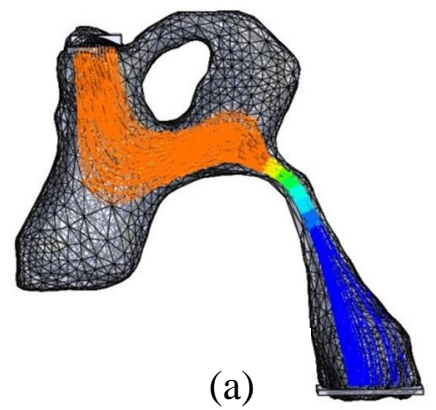

Fig. 4: Streamlines and pressure distribution in ROI for normal cases:

a) $0.0108 \mathrm{ml} / \mathrm{s}$, and b) $0.01167 \mathrm{ml} / \mathrm{s}$.
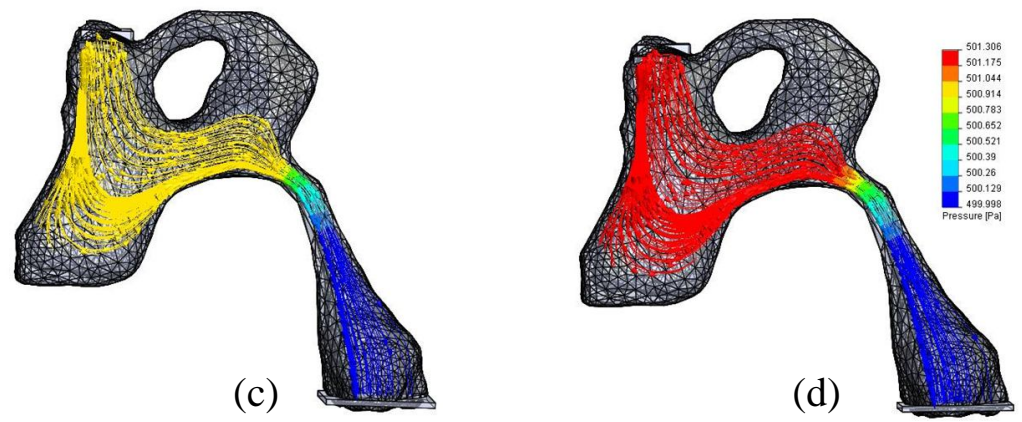

Fig. 5: Streamlines and pressure distribution in ROI for hydrocephalus cases:

c) $0.0162 \mathrm{ml} / \mathrm{s}$, and d) $0.0189 \mathrm{ml} / \mathrm{s}$.

Based on Fig. 4 and Fig. 5, inlets pressure was at its maximum value and while the CSF flow through down to the inferior end of the aqueduct of Sylvius, the pressure decreasing and 
reached its lowest value. We can see as the flow rate increases, the artificial flow tends to fulfil the region of interest as much as possible. Since the wall of the model regarded as rigid, the expansion of the model was neglected.

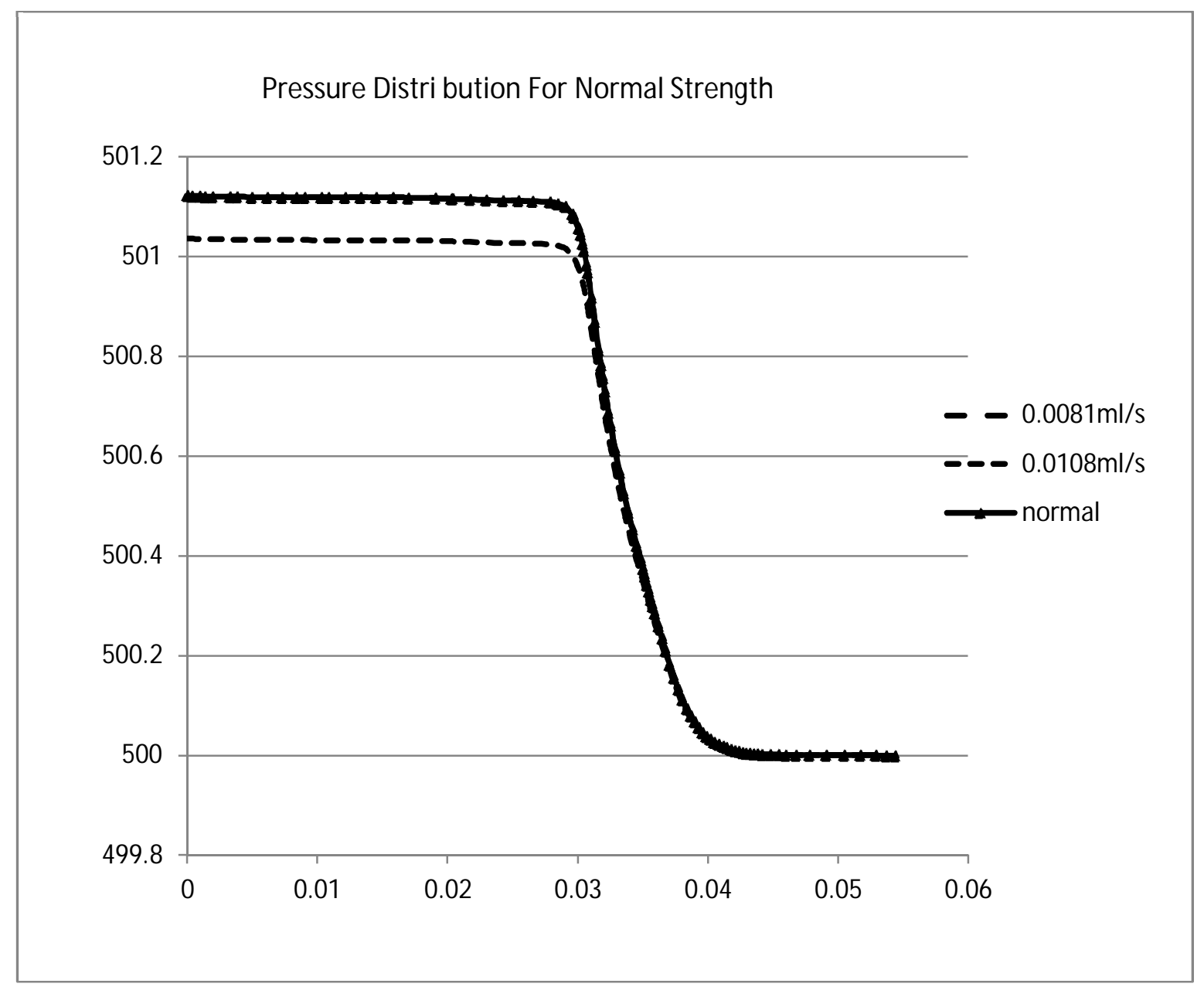

Fig. 6: Graph for pressure distribution for normal case. 


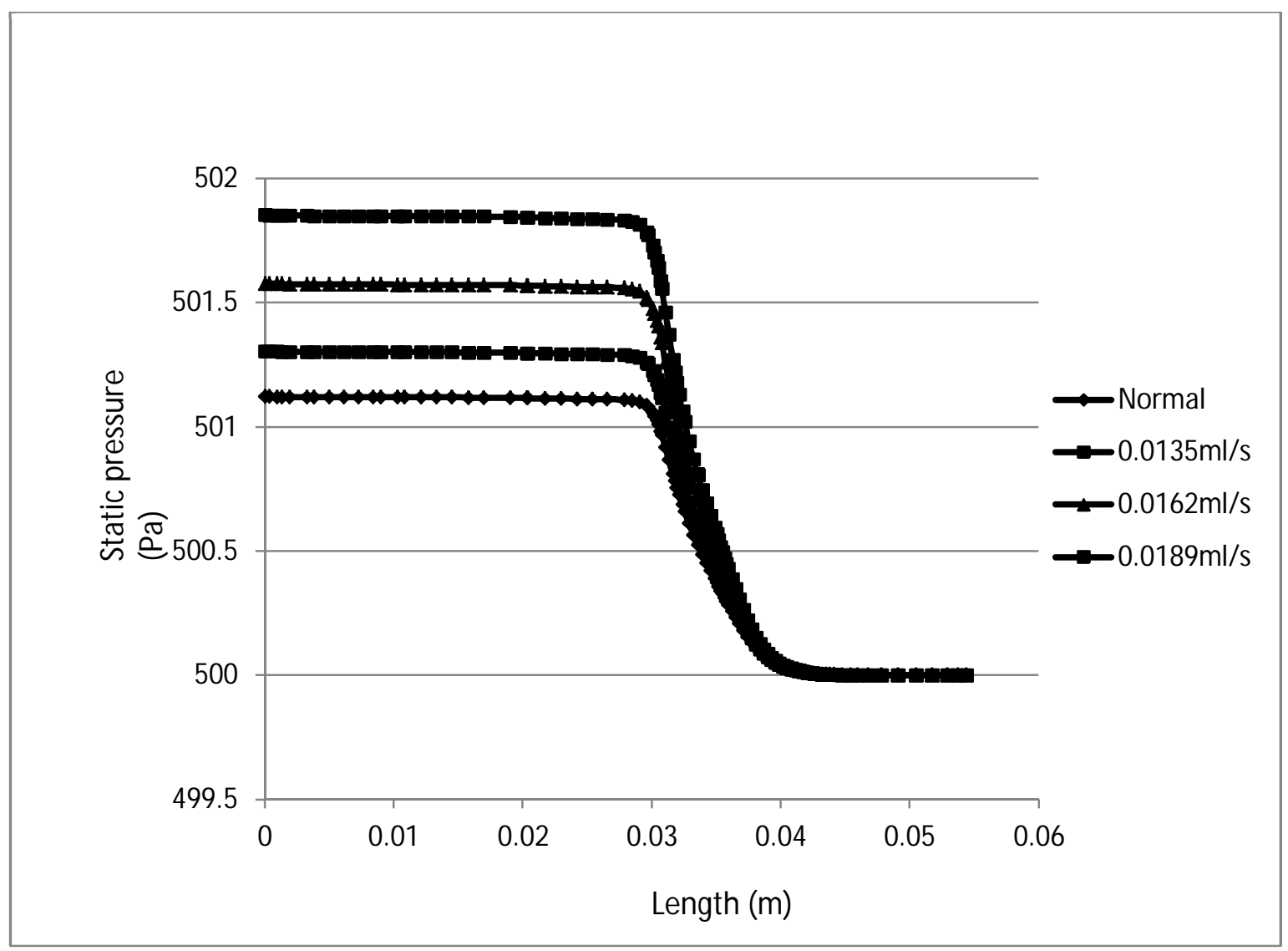

Fig. 7: Graph for pressure distribution for hydrocephalus case.

Based on the shown graph, as the CSF flow reach at aqueduct of Sylvius at nearly $0.025 \mathrm{~m}$ from the Foramen of Monro and flow through along it at approximately $0.01 \mathrm{~m}$, we can see a sharp pressure drop indicating that the narrow channel of the aqueduct does the effect to the flow characteristic.

It has been found that pressure drop were present between the Foramen of Monro and the inferior end of the aqueduct of Sylvius. In Fig. 4, $0.65 \mathrm{~Pa}$ and $0.72 \mathrm{~Pa}$ of pressure drop were successfully recorded. These results can be acceptable for normal patient based on the findings by Aroussi [5]. While for hydrocephalus cases in figure 5, the pressure drop recorded at 0.82 and $1.21 \mathrm{~Pa}$. The latter figure show slightly higher than $1.0 \mathrm{~Pa}$ as it can be regarded as the boundary value for the normal cases based on Jacob [6] findings. We can concluded that as the inlets flow rate increases, so does the drop in the region of interest which match to Helen`s [7] work on her research on hypothesis for hydrocephalus.

A normal model was generated while the stenosis model was taken to be of the normal aqueduct shape, but reduced in size with approximately $10 \%$ to $80 \%$ with an increment of $10 \%$ in reduced cross-sectional areas. A normal flow rate was defined at the inlets. The results are shown in Fig. 8 and Fig. 9 whereas the total pressure drop for each stenosis size is shown in Fig. 10. 


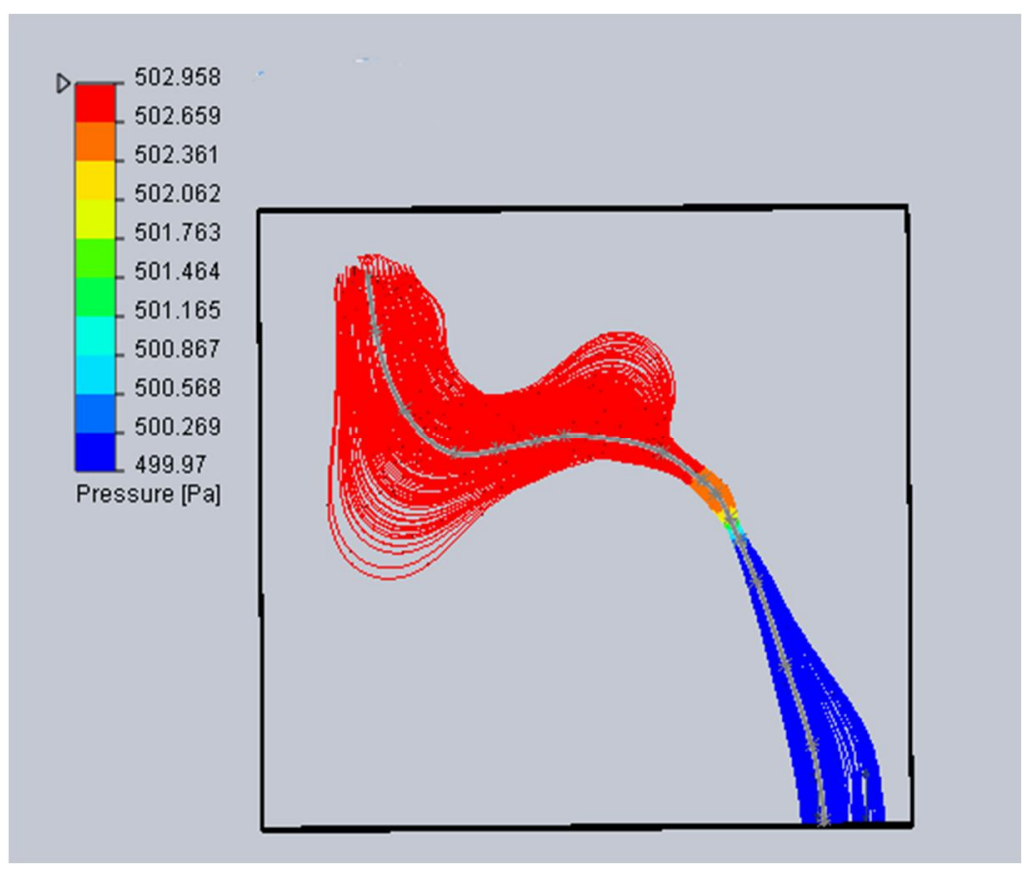

Fig. 8: Streamlines and pressure distribution in ROI with 50\% stenosis size (3 Pa of pressure drop).

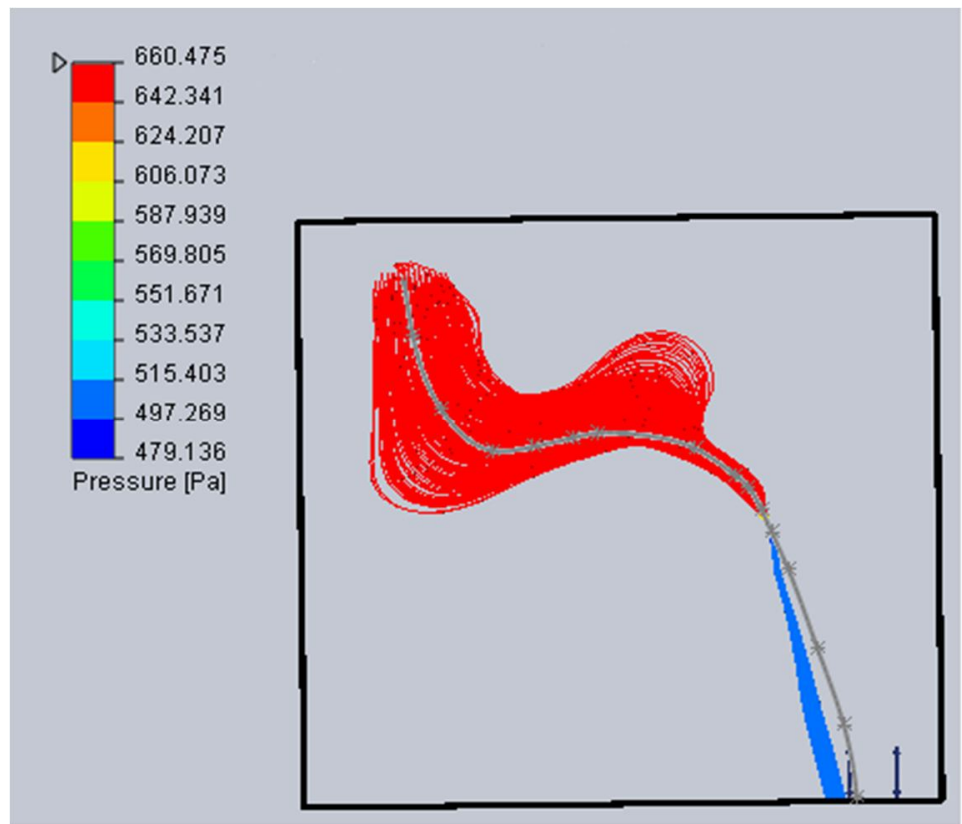

Fig . 9: Streamlines and pressure distribution in ROI with $80 \%$ stenosis size (181 Pa of pressure drop). 


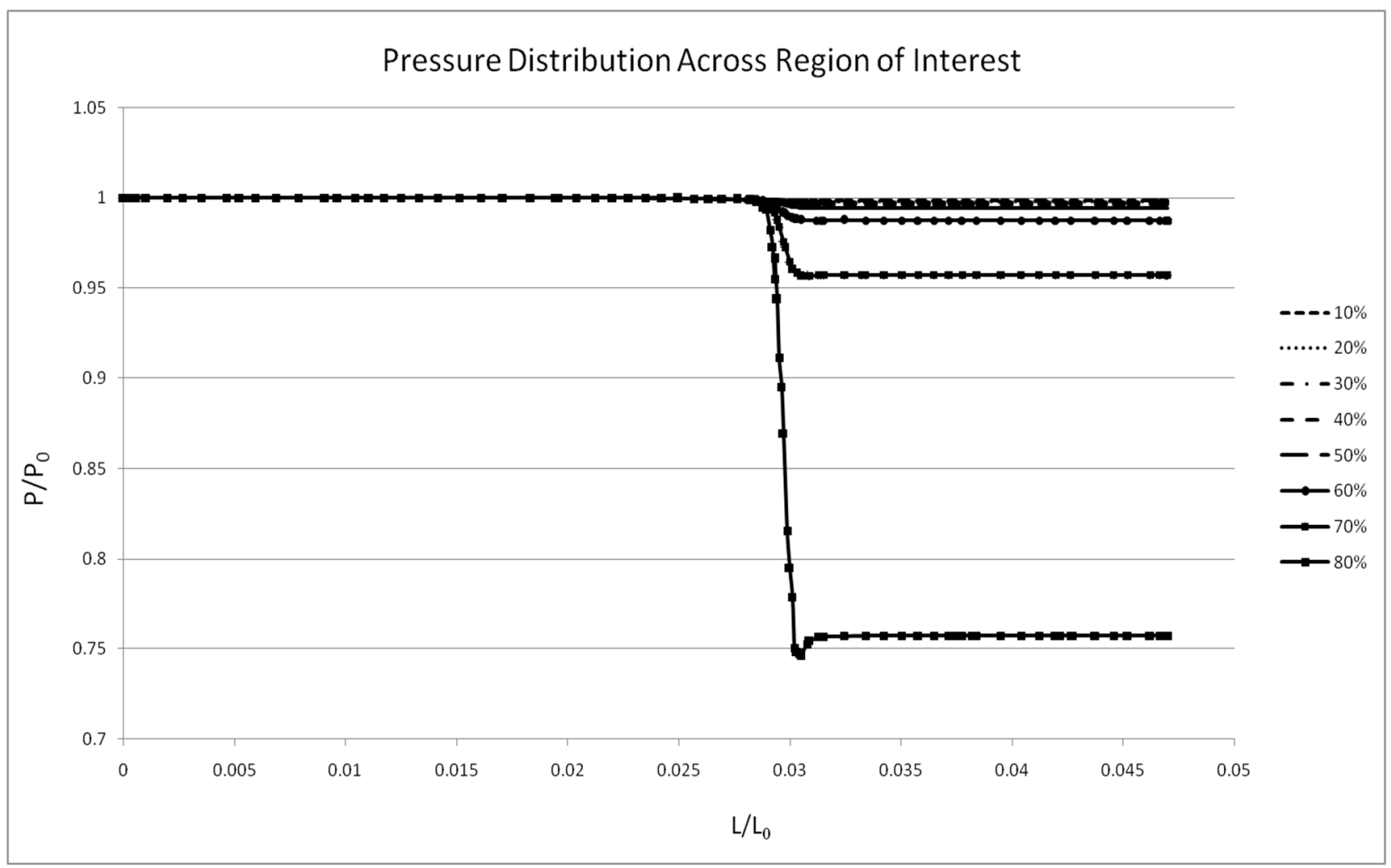

Fig. 10: Graph for pressure distribution in ROI for each stenosis size.

In Fig. 8 and 9, the shape of the stenosed aqueduct is the same as that of the normal aqueduct, only of smaller dimensions. As expected, the flow decreases for a given pressure difference as the aqueduct narrows. The flow was obviously obstructed by the blockage that only a small volume of CSF managed to drive flow through the narrowed aqueduct. Based on the graph on figure 10,we can see that as the stenosis size increase, the pressure drop increase. The sharp fall that begins at the inferior end of the Foramen of Monro and along the aqueduct demonstrates that the CSF was accelerating. Since the stenosis is not modelled based on the actual shape and the exact location of it is still undefined, we assumed that the obtained result remain ambiguous. But as the results fall within the range that found in Jacobson [8] and Parkkola [9] work, we come to an agreement that the results are acceptable.

As all the results were the outcome from a rigid walled ROI, non-pulsatile nature flow of $\mathrm{CSF}$, excluded gravity and external hydrodynamics pressure from the surrounded brain tissues, these result represents a crude approach for the quantification of the pressure in the third ROI. Although the results seem not to abide the accurate medical findings by other practitioners and researchers, they can be served as groundwork for further studies.

\section{CONCLUSION}

CFD simulations was used to obtain ventricle geometry from anatomical MRI scans. In EFD, various flow rates were artificially defined at inlets and stenosed aqueduct was modeled within the domain of the geometry. The results show as the flow rate increase, the pressure drop of CSF in the ROI proportionally increased. For normal CSF flow rate, the presence of 
stenosis in the aqueduct demonstrates a significant increased pressure drop. With further refinement and input based on the clinical information gathered from patients with hydrocephalus and their treatment outcome the information obtained from this study can be useful to aid in the design of medical devices that can be used to monitor or treat hydrocephalus. It would also be interesting to explore further to see if a simple method or software can be designed to help radiologists distinguish between hydrocephalus and benign enlargement of the subarachnoid spaces.

\section{ACKNOWLEDGEMENT}

This research was fully supported by grant number 79414 from the Faculty of Medical Engineering and Health Science of University Technology Malaysia.

\section{REFERENCES}

[1] Davson, H., and Segal, M. B., 1996, Physiology of the CSF and Blood-Brain Barriers, CRC Press, Boca Raton.

[2] Friese, S., Klose, U., and Voigt, K., 2002, “Zur Pulsation des Liquor cerebrospinalis,"Klin. Neurorad. 12, pp. 67-75.

[3] V. Kurtcuoglu, M. Soellinger, P. Summers, K. Boomsma,D. Poulikakos, P. Boesiger, and Y. Ventikos.,(2007).Computational investigation of subject-specific cerebrospinal fluid flow in the third ventricle and aqueduct of sylvius. Journal of Biomechanics, 40(6):1235-1245.

[4] A. Andreas A. Linninger Michalis Xenos, David C. Zhu, MahadevaBharath R. Somayaji, Srinivasa Kondapalli,(2007) Cerebrospinal Fluid Flow in the Normal and Hydrocephalic Human Brain. IEEE TRANSACTIONS ON BIOMEDICAL ENGINEERING, VOL. 54, NO. 2.

[5] A.Aroussi , (2006 ). 3D Visualization of Cerebrospinal Fluid Flow Within The Human Central Nervous System.

[6] Jacobson E.E Flecther , (1996),Fluid Dynamics of Cerebral Aqueduct,Pediatric Neurosurgery 24,229-236.

[7] Helen Williams,(2008). A unifying hypothesis for hydrocephalus, Chiari malformation,syringomyelia, anencephaly and spina bifida.

[8] E.E Jacobson,D.F. FlectherM.K. Morgan,(1999)Computer modelling of cerebrospinal fluid flow dynamics of aqueduct stenosis. Medical \& Biological Engineering \& Computing, Vol 37 ,59-63.

[9] Parkkola RK, Komu MES, Kotilainen EM, Valtonen SO, Thomsen C, Gideon P (2000), CSF flow in patients with dilated ventricles studied with MR imaging. Eur Radiol ;10:1442-6. 